\title{
Tigers, markets and palm oil: market potential for conservation
}

\author{
IAN J. BAteMAN, BRENDAN Fisher, EMILY FitzheRBeRT \\ David GLEW and Roвin NaIdoo
}

\begin{abstract}
Increasing demand for cooking oil and biofuels has made palm oil, $>80 \%$ of which is grown in South-east Asia, the dominant globally traded vegetable oil. However, this region is host to some of the world's most biodiverse and threatened tropical forests. Strategic engagement with commercial operations is increasingly recognized to be an essential part of the solution for raising funds for conservation initiatives, raising consumer consciousness and potentially stemming environmental degradation. Linking market incentives towards conservation is also of critical importance because it is becoming widely recognized that conservation needs to begin to address the wider countryside (outside protected areas) where human-wildlife interactions are frequent and impacts are large. Using the Sumatran tiger Panthera tigris sumatrae as both a threatened species in its own right and emblematic for wider species diversity, we show that western consumers are willing to pay a significant premium for products using palm oil grown in a manner that reduces impacts on such species. Results suggest that the price premium associated with a 'tiger-friendly' accreditation may provide a useful additional tool to raise conservation funds and, within the right institutional context, serve as an inducement to address the problem of habitat and species loss.
\end{abstract}

Keywords Economic valuation, environmental economics, green markets, palm oil, Panthera tigris sumatrae, Sumatran tiger

\section{Introduction}

The current unprecedented increase in global food 1 prices $(\mathrm{FAO}, 2007)$ is nowhere better demonstrated than with respect to palm oil, the price of which increased c. $70 \%$ from 2007 to 2008 (HGCA, 2008). More than $80 \%$ of oil palm is grown in South-east Asia (Malaysia and Indonesia). This region encompasses four biodiversity hotspots and is experiencing some of the highest rates of deforestation (Sodhi et al., 2004), and it has been estimated

IAN J. BATEMAN, BRENDAN Fisher (Corresponding author), EMILY Fitzherbert and David Glew Centre for Social and Economic Research on the Global Environment, University of East Anglia, Norwich, NR4 7TJ, UK. E-mail bpfisher@princeton.edu

Robin NAIDoo Conservation Science Program, World Wildlife Fund, Washington, DC, USA

Received 16 January 2009. Revision requested 16 March 2009.

Accepted 20 April 2009. that during $1990-2005$ up to $59 \%$ of Malaysian and at least $56 \%$ of Indonesian oil palm expansion directly replaced forest (Koh \& Wilcove, 2008). Grown in extensive monocultures, oil palm plantations support significantly fewer species than tropical forests (Fitzherbert et al., 2008; Koh \& Wilcove, 2008; Danielsen et al., 2009). With expanding world food consumption and the advent of biofuels, demand for palm oil continues to rise and the potential for expanding oil palm agriculture to cause extensive future forest loss is huge. Within South-east Asia most expansion seems set to occur within the Indonesian archipelago. If this occurs at the expense of native forest, the result may be catastrophic for the region's biodiversity (Fitzherbert et al., 2008).

Rising concerns regarding the negative social and environmental impacts of palm oil production prompted the establishment of the Roundtable on Sustainable Palm Oil (RSPO, 2009), which aims to promote sustainably produced palm oil. RSPO certification requires commitment by palm oil producers to a range of sustainability criteria (including managing plantations for threatened species, controlling for soil erosion, groundwater and chemical pollution, and continuous monitoring of potential environmental/habitat impacts). However, it is widely accepted that the social and conservation elements are the most difficult and costly to implement (Bangun, 2006). Preventing forest loss to plantation development is the most important action for mitigating biodiversity impacts (Koh \& Wilcove, 2008; Phalen et al., 2009). This is where certification of sustainably produced palm oil can help, as plantations recently converted from primary forest or high conservation value habitat are excluded from RSPO accreditation (RSPO certification criteria 5.2).

Global agricultural expansion and the associated loss and degradation of native habitat are one of the principal causes of biodiversity loss (Tilman et al., 2001). Decisions about land use are based primarily on economic criteria and sustainable solutions for multiple-use landscapes will only be found through engagement with economic incentive systems (Naidoo et al., 2006). For the palm oil market to be a tool for raising conservation funds and stemming future expansion into native forests, strong monitoring institutions are essential but two additional conditions are (1) a means of identifying responsible producers and (2) a means of rewarding them.

A major step towards satisfying the first condition may come through certification systems administered by 
organizations such as the RSPO (although vigilance is needed with regard to the administration of any such certification scheme to ensure that it remains independent of producers; see FERN, 2002, in relation to forest certification schemes). Satisfying the second condition may come from so-called green markets, which provide a mechanism by which commercial activities are incentivized to engage with conservation objectives (Ferraro et al., 2005; Butler \& Laurance, 2008). Green markets depend on the willingness of some of the world's most economically powerful consumers (e.g. those in the developed world) to pay a significant price premium for preferred ways of producing what are, in other respects, identical goods. Cases such as the Forest Stewardship Council timber certification scheme (Nussbaum \& Simula, 2004) or the dominating market penetration of dolphin-friendly tuna (Teisl et al., 2002; Jacquet et al., 2010) demonstrate the willingness of consumers to pay for process as well as product.

To tap into these markets flagship species have long been used as emblems of conservation agendas: using charismatic taxa, usually mammals and birds, to capture public sympathy. Such species perform a socio-economic role in soliciting broad support for nature conservation and by definition are not required to perform as an ecological surrogate for other components of biological diversity or ecosystem function (Caro \& O'Doherty, 1999). Although there is continued debate over the value of surrogate species in conservation prioritization (Sergio et al., 2008) and a shift to conservation focused on ecosystem functions and services (Millennium Ecosystem Assessment, 2005), flagship species remain an effective method of presenting complex issues to a wider audience.

In this study we investigated the potential for a price premium for certified palm oil by linking palm oil production with the plight of the Sumatran tiger Panthera tigris sumatrae, one of the world's most threatened and emblematic megafauna (Mills et al., 2007). This work was conducted in connection with the Zoological Society of London's Indonesia tiger conservation programme (Maddox et al., 2007), which uses the Sumatran tiger as its flagship species and aims to document how palm oil conversion influences biodiversity. The present study complements our ongoing research quantifying the costs of producing palm oil in ways that reduce impacts on species.

\section{Methods}

Our experimental design focused on an everyday good that increasingly contains palm oil: vegetable margarine. Investigations into the palm oil premium were informed by UK official guidelines for conducting such studies (Bateman et al., 2002). We conducted a split-sample survey of 600 consumers at locations across the UK. Survey respondents were given a simple choice between two tubs of margarine, identical in all respects except that one was designated as being produced using 'tiger-friendly' techniques and offered at different prices relative to a conventionally produced product. The price of the two goods was varied across treatments and respondents asked to state which of the two they would choose at the price shown. Prices were then adjusted in response to these answers (e.g. if the tigerfriendly good was initially chosen then its price was increased) and respondents again asked to choose between the two products. Finally respondents were asked to state the maximum amount they would be prepared to pay for the tiger-friendly good. Economists define this as the economic value of the good and it is this amount that we refer to subsequently.

The study was designed to examine two factors that could influence the extent of any tiger-friendly price premium: the quality of the good and the level of marketing used. To assess quality effects half of the respondents were presented with a high-quality conventionally produced margarine alongside an identical quality (and brand) of the tiger-friendly margarine, and the price premium evaluated. The remainder of the sample faced a similar procedure except that now both the conventionally produced and tiger-friendly margarine was a lower quality brand. The entire sample was then cross-cut by three levels of marketing information so as to make six treatments in all. The levels of marketing information were nested such that the most basic level is then added to so as to make the intermediate level and then all of that information is added to make the highest level. The lowest of these marketing levels (adLow) provided individuals with the following deliberately general and non-quantified statement:

If you purchase the tiger-friendly margarine, some of the money you will spend will go towards protecting tigers in Sumatra. Specifically it will protect the land where the tigers hunt.

The second level (adMedium) comprised the former statement and added the following quantification of the rate at which the tiger population is being depleted:

In 1978 there were roughly 1,000 tigers. Due to hunting and destruction of the jungle there are now only around 500 left.

The final level of information (adHigh) comprised both the above statements and added colour images of Sumatran tiger adults and cubs. This therefore brings together general, quantitative and visual image information and represents the maximum realistic marketing likely to be undertaken in a mass-market, commercial setting.

The above design gives us six distinct combinations of quality (low and high) and marketing (low, medium and high). Respondents were randomly allocated to each of these treatments. The questionnaire was extensively piloted $(n=150)$ on university students and employees. The main 
survey was undertaken using face-to-face interviewing of households and of individuals at supermarkets at four cities across the UK, with a total sample of 600 that was almost perfectly divided across the six treatments. While we do not claim national representativeness, the sample size captured a good spread of variation in socio-economic and demographic covariates, suggesting that results should correspond to a large segment of the population.

\section{Results}

Tests across a wide variety of socio-economic and demographic characteristics confirmed that there were no significant differences between the various subsamples defined by each of the treatments (i.e. the results of the experiment are not confounded by differences in respondent age, income, gender, group membership or interview location).

Detailed results and confirmation of the statistical significance of the price premium is given in Table 1 , which reports mean willingness to pay for the tiger-friendly good under each of the treatments. The two effects investigated, quality and marketing, show clear trends. A clear quality effect is observable, with willingness to pay for the tigerfriendly product consistently higher at the upper quality end of the market for margarine than at the lower end. Irrespective of quality higher levels of marketing lead to higher willingness to pay. Multivariate modelling of the willingness to pay responses (Bateman et al., 2009) confirmed the statistical significance of the price, quality and marketing effects $(\mathrm{P}<0.01)$. Although the socio-economic and demographic characteristics of respondents exhibited expected effects on valuations (e.g. those with higher incomes had higher willingness to pay) only one of these factors proved statistically significant: a higher willingness to pay from respondents interviewed at supermarkets. This suggests that those who actually make food expenditure decisions are more willing to pay the tiger-friendly price premium, a result that of itself enhances the validity of findings.
Substantial and significant price premiums exist for tiger-friendly palm oil across both quality and marketing levels (Table 1). In relative terms, the price premium is greatest for lower quality products. For the highest level of marketing, the premium for tiger-friendly margarine is $56 \%$ at the low quality end of the margarine market and $36 \%$ at the high end of this market. In contrast, the absolute value of this premium is greatest at the upper end of the market (Table 1) where consumers with higher gross incomes expressed their preference for production mode over price.

\section{Discussion}

The success of market-based conservation mechanisms, such as eco-labels, depends on the presence of consumer demand, reliable certification, tangible rewards for producers and discernible environmental benefits (Kaiser \& Edwards-Jones, 2005). We have shown that a consumer demand for eco-labelled palm oil exists and that using a charismatic high-profile mammal such as the tiger as the public face of certified palm oil can prove effective in eliciting consumer preferences for such products and thus offer the potential to raise funds and awareness for species conservation. The RSPO seems capable of providing the necessary organization required to ensure integrity in the standards of such an eco-label as well as ensuring the certified producers accrue benefits. The term 'tiger friendly' is of course a relative concept. Even the most responsibly run oil palm plantations will remain inferior to virgin forest (Fitzherbert et al., 2008). The extent to which any price premium for a more environmentally friendly palm oil contributes to slowing the destruction of virgin forests depends on the institutions that will govern the production (i.e. national governments, NGOs, market cooperative). Certification is not a mechanism that can, in itself, halt the destruction of primary forests. However, the existence of a price premium does put pressure on conventional producers, who would be receiving lower profits. Even if demand for conventional palm oil remains high, producers tend to prefer higher profits to lower profits and hence

TABLE 1 Mean willingness to pay (i.e. the economic value of the good; see text for details) for two qualities of tiger-friendly margarine, each with three levels of marketing (with $95 \%$ confidence interval, CI, and percentage price premium in excess of the conventionally produced product). All premiums are statistically significant at $\mathrm{P}<0.05$.

\begin{tabular}{lll}
\hline & $\begin{array}{l}\text { Mean willingness to pay for } \\
\text { lower quality product, GBP } \\
\text { (CI, \% premium) }\end{array}$ & $\begin{array}{l}\text { Mean willingness to pay for } \\
\text { higher quality product, GBP } \\
\text { (CI, \% premium) }\end{array}$ \\
$\begin{array}{l}\text { Level of marketing } \\
\begin{array}{l}\text { Lowest level: no information on tiger numbers or } \\
\text { images (adLow) }\end{array}\end{array}$ & $1.03(0.98-1.07,37 \%)$ & $1.29(1.24-1.33,15 \%)$ \\
$\begin{array}{l}\text { Medium level: information on tiger numbers but } \\
\text { no images (adMedium) }\end{array}$ & $1.10(1.05-1.15,47 \%)$ & $1.35(1.30-1.40,21 \%)$ \\
$\begin{array}{l}\text { Highest level: information on tiger numbers and } \\
\text { images (adHigh) }\end{array}$ & $1.17(1.11-1.23,56 \%)$ & $1.52(1.47-1.57,36 \%)$ \\
\hline
\end{tabular}


a market shift is possible, as has happened in other cases (e.g. fish certified by the Marine Stewardship Council in Walmart; Weiss, 2006). Given the future potential demand for palm oil, this shift would only be effective in the long term if deforestation was brought under control.

RSPO members are responsible for about half of the world's palm oil supply (RSPO, 2009) and for a major realignment of oil palm production overall the remaining producers will have to see real economic benefits to offset costs of biodiversity-friendly production. The price premiums described here could provide that incentive by compensating the adoption of more costly but responsible production methods. There is evidence that similar price premiums for shade-grown coffee have slowed coffee intensification (Steffan-Dewenter et al., 2007), and movements such as the fair-trade movement have shown the power of price premiums in generating major change in production patterns. Therefore, understanding the magnitude of a possible price premium may also help groups like RSPO recruit producers to their membership.

There is some evidence from previous studies that certain consumers overstate willingness to pay in preference surveys such as this. In part, this arises because of uncertainty respondents experience regarding whether schemes will fully deliver the benefits they claim (Powe \& Bateman, 2004). A number of studies have estimated the degree of this 'hypothetical bias' by comparing stated willingness to pay with subsequent actual payments. In a recent metaanalysis of such studies Murphy et al. (2005) report that stated values were typically 1.5 times the actual values. While the degree of overstatement varies from study to study, such a figure suggests our estimates of willingness to pay should be reduced. Whether producers should react to such information by aiming their conservation-grade production at the higher or lower end of the market depends in part on relative sales volumes.

Critics of market approaches to conservation point to studies showing that market incentives have performed poorly for conservation and have advocated a direct payment approach to conservation (Ferraro et al., 2005). This approach may be highly effective where such purchases do in fact occur. However, one of the paradoxes facing the conservation movement is that, while there is plenty of evidence of a commonplace concern for the preservation of species in developed countries, this is not reflected well in explicit donations to conservation groups (Pearce, 2007). A certification scheme for palm oil could overcome the inherent inertia in direct payments, i.e. it is easier to buy margarine than donate to a conservation organization.

Engaging strategic industries is a growing approach to forest conservation (Butler \& Laurance, 2008). As the first plantations are certified and RSPO palm oil becomes available (Green Palm Sustainability, 2010), there is an urgent need to strengthen the engagement of the oil palm industry in forest conservation. The tying of certification to a price premium may provide groups such as the RSPO with a means of meeting certified palm oil production costs in the shorter rather than longer term, a distinction that could mean the difference between survival and extinction for the Sumatran tiger and associated species.

We inhabit mainly domesticated and human-dominated landscapes (Kareiva et al., 2007; Ellis \& Ramankutty, 2008). In light of this, conservation must consider wider landscape initiatives integrating natural areas with more human managed mosaics to ensure species persistence and population behaviours as well as wider ecosystem processes (Wilcove, 2008). While there is no substitute for primary forests (even secondary forests are being proposed as critical for conservation in oil palm landscapes; Koh \& Wilcove, 2008), we need to consider the costs and benefits of non-traditional approaches for species conservation (Gullison, 2003), especially in a world of growing global demand for primary products.

\section{References}

Bangun, D. (2006) Sustainable Production of Palm Oil: Complicated and Costly Yet Necessary. International Oil Palm Conference 2006, Nusa Dua, Bali, Indonesia.

Bateman, I.J., Carson, R.T., Day, B., Haneman, W.M., Hanley, N., Hett, T. et al. (2002) Economic Valuation with Stated Preference Techniques: A Manual. Edward Elgar Publishing, Cheltenham, UK.

Bateman, I.J., Coombes, E., Fisher, B., Fitzherbert, E., Glew, D.W. \& Naidoo, R. (2009) Saving Sumatra's Species: Combining Economics and Ecology to Define an Efficient and Selfsustaining Programme for Inducing Conservation within Oil Palm Plantations. CSERGE Working Paper EDM-2009-03. Centre for Social and Economic Research on the Global Environment, University of East Anglia, Norwich, UK.

ButLer, R.A. \& LA U RA NCE, W.F. (2008) New strategies for conserving tropical forests. Trends in Ecology \& Evolution, 23, 469-472.

Caro, T.M. \& O'Doherty, G. (1999) On the use of surrogate species in conservation biology. Conservation Biology, 13, 805-814.

Danielsen, F., Beukema, H., Burgess, N., Parish, F., Bruhl, C.A., Donald, P.F. et al. (2009) Biofuel plantations on forested lands: double jeopardy for biodiversity and climate. Conservation Biology, 23, 348-358.

Ellis, E.C. \& Ramankutty, N. (2008) Putting people in the map: anthropogenic biomes of the world. Frontiers in Ecology and the Environment, 6, 439, 523-523.

FAO (Food and Agriculture Organization) (2007) Food Outlook: Global Market Analysis. FAO, Rome, Italy.

FERN (Forests AND European Union Resources Network) (2002) Cleaning up ECAs: The Possibilities for Action at the EU Level. FERN, Moreton in the Marsh, UK.

Ferraro, P.J., Uchida, T. \& Conrad, M. (2005) Price premiums for eco-friendly commodities: are 'green' markets the best way to protect endangered ecosystems? Environmental and Resource Economics, 32, 419-438.

Fitzherbert, E.B., Struebig, M.J., Morel, A., Danielsen, F., Bruhl, C.A., Donald, P.F. \& Phalen, B. (2008) How will oil palm expansion affect biodiversity? Trends in Ecology \& Evolution, 23, 538-545. 
Green Palm Sustainability (2010) Http://www.greenpalm.org [accessed 13 January 2010].

Gullison, R.E. (2003) Does forest certification conserve biodiversity? Oryx, 37, 153-165.

HGCA (Home Grown Cereals Authority) (2008) Vegetable Oil Update. HGCA, London, UK.

Jacquet, J., Hocevar, J., Lai, S., Majluf, P., Pelletier, N., Pitcher, T. et al. (2010) Conserving wild fish in a sea of marketbased efforts. Oryx, 44, 45-56.

Kaiser, M.J. \& Edwards-Jones, G. (2005) The role of eco-labeling in fisheries management and conservation. Conservation Biology, 20, 392-398.

Kareiva, P., Watts, S., McDonald, R. \& Boucher, T. (2007) Domesticated nature: shaping landscapes and ecosystems for human welfare. Science, 316, 1866-1869.

Кон, L.P. \& Wilcove, D.S. (2008) Is oil palm agriculture really destroying tropical biodiversity? Conservation Letters, 1 , $60-64$.

Maddox, T.M., Priatna, D., Gemita, E. \& Selampassy, A. (2007) The Conservation of Tigers and Other Wildlife in Oil Palm Plantations, Jambi Provice, Sumatra, Indonesia. ZSL Conservation Report No. 7. Zoological Society of London, London, UK.

Mills, J., O’Brien, T., Shrestha, M., Simons, R. \& Songer, M. (2007) The fate of wild tigers. BioScience, 57, 508-514.

Murphy, J.J., Allen, P.G., Stevens, T.H. \& Weatherhead, D. (2005) A meta-analysis of hypothetical bias in stated preference valuation. Environmental and Resource Economics, 30, 313-325.

Naidoo, R., Balmford, A., Ferraro, P.J., Polasky, D. Ricketts, T.H. \& Rouget, M. (2006) Integrating economic costs into conservation planning. Trends in Ecology \& Evolution, 21, 681-687.

Nussbaum, R. \& Simula, M. (2004) Forest Certification: A Review of Impacts and Assessment Frameworks. Commissioned Paper for The Forests Dialogue Certification Meeting, 19-21 October 2004, Maidenhead, UK.

PEARCE, D.W. (2007) Do we really care about biodiversity? Environmental and Resource Economics, 37, 313-333.

Phalan, B., Fitzherbert, E.B., Rafflegeau, S., Struebig, M.J. \& Verwilghen, A. (2009) Conservation in oil-palm landscapes. Conservation Biology 23, 244-245.

Powe, N.A. \& BAteman, I.J. (2004) Investigating insensitivity to scope: a split-sample test of perceived scheme realism. Land Economics, 80, 258-271.

RSPO (2009) Roundtable on Sustainable Palm Oil. Http:// www.rspo.org [accessed 13 January 2010].
Sergio, F., Caro, T.M., Brown, D., Clucas, B., Hunter, J., Ketchum, J. et al. (2008) Top predators as conservation tools: ecological rationale, assumptions and efficacy. Annual Reviews of Ecology and Systematics, 39, 1-19.

Sodri, N.S., Koh, L.P., Brook, B.W. \& NG, P.K.L. (2004) Southeast Asian biodiversity: an impending disaster. Trends in Ecology \& Evolution, 19, 654-660.

Steffan-Dewenter, I., Kessler, M., Barkmann, J., Bos, M.M., Buchori, D., Erasmi, S. et al. (2007) Trade-offs between income, biodiversity and ecosystem functioning during tropical rainforest conversion and agroforestry intensification. Proceedings of the National Academy of Sciences, USA, 104, 4973-4978.

Teisl, M.F., Roe, B. \& Hicks, R.L. (2002) Can eco-labels tune a market? Evidence from dolphin-safe labelling. Journal of Environmental Economics and Management, 43, 339-359.

Tilman, D., Fargione, J., Wolff, B., D’Antonio, C., Dobson, A.P., How ARTH, R. et al. (2001) Forecasting agriculturally driven global environmental change. Science, 292, 281-284.

Weiss, K.R. (2006) Altered oceans: not enough fish in the sea. Los Angeles Times, 26 November 2006. Http://articles.latimes.com/ 2006/nov/26/nation/na-savefish26 [accessed 18 February 2010].

Wilcove, D.S. (2008) No Way Home: The Decline of the World's Great Animal Migrations. Island Press, Washington, DC, USA.

\section{Biographical sketches}

IAN BATEMAN was once a respectable economist but has spent 20 years bringing the complexities of the real world, especially spatial issues, into environmental economic analyses. He also examines issues associated with valuing the benefits of non-market goods such as those associated with ecosystem services. BRENDAN FISHER's research focuses on the conservation-development nexus, using the tools and approaches of ecosystem services, poverty alleviation and valuation. He also documents the presence-absence of chickens across the tropics. Emily Fitzherbert researches the ecology-human interface. She has studied the impact of oil palm plantations on biodiversity in Indonesia and lion killing in Tanzania. DAVID GLEW focuses on the sustainable development of alternatives to goods and services that are currently reliant on petrochemicals, in particular the socio-economic and environmental issues relating to second generation biofuels. RовіN NaIDoo's research interests include mapping and valuing the costs and benefits of conservation. 